\title{
非対称波浪下における浮遊砂濃度と漂砂量 \\ SUSPENDED SEDIMENT CONCENTRATION AND SEDIMENT TRANSPORT RATE UNDER ASYMMETRIC WAVES
}

\author{
伊福誠*・柿沼忠男**・後藤博光*** \\ By Makoto IFUKU, Tadao KAKINUMA and Hiromitsu GOTOH
}

\begin{abstract}
Numerical analysis was carried out to obtain the near-bottom flow velocity and the suspended sediment concentration. The results were compared to Noda's, authors' and Nielsen's field data and the laboratory data obtained by Deigaard et al.. The nearbottom flow velocity was computed by the turbulent boundary layer theory with the timedependent eddy viscosity, and the suspended sediment concentration was computed by the turbulent diffusion theory with the time-dependent turbulent diffusion coefficient, using the concentration of reference level estimated by Kalkanis' theory.

The computed phase lag between the cross-shore velocity and suspended sediment concentration agrees well with those observed. The computed distributions of the mean suspended sediment concentration with the time-dependent turbulent diffusion coefficient proposed by authors agree well with the measured distributions.

Keywords: suspended sediment, time-dependent eddy viscosity, turbulent diffusion coefficient, sediment transport rate
\end{abstract}

\section{1. 緒 論}

波動場における底質の輸送現象を調べてゆくためには 波による底質の浮遊機構を詳細に把握することが重要と なる．波動場における浮遊砂に関する研究は古くからな されており, Fairchild ${ }^{1)}$, Homma・Horikawa ${ }^{2)}$, 野田 ${ }^{3)}$ は それぞれ siphon, pumped sampler, suspended sampler を用いて浮遊砂を採集しその特性について調べている. しかしながら, それらの方法では浮遊砂濃度の時間変化 を知ることはきわめて困難であった．近年，測定機器の 精度向上とも相まって本間ら ${ }^{4)}$, 野田・岩佐 ${ }^{5)}$, Sleath ${ }^{6)}$, Brennikmeyer ${ }^{7)}$ よび Wright $ら^{8)}$ は水槽実験や現地観 測で浮遊砂濃度の時間変化についての記録を得, 浮遊砂 濃度と波の特性との関連について従来よりも詳しい検討 がなされるようになった。

本間ら ${ }^{4)}$, Sleath ${ }^{6)}$ はそれぞれ規則波，振動流による 実験において砂漣上の固定点で濃度の時間変化を調べ, その結果波 1 周期間に数個のピークが生じ, 最大濃度は 境界層外縁の流速が岸向きから沖向きに変わる位相で生

* 正会員 工修 愛媛大学講師 工学部海洋工学科 ( ₹790 松山市文京町 3 番)

** 正会員 工博 愛媛大学教授 工学部海洋工学科 (同上)

*** 学生会員 愛媛大学大学院工学研究科 (同上)
ずることを得ている．濃度と流速の位相差は浮遊砂雲の 移流ということで説明される ${ }^{9)}$ が，彼らはこの位相差を 基礎方程式に基づく解析によって定量的には説明してい ないようである. Nielsen ${ }^{10)}$ は境界層外縁の流速が岸向 きから沖向きに変わる位相と沖向きから岸向きに変わる 位相で濃度が高くなることを考慮し，そうした位相で第 1 ピークと第 2 ピークをもつ“pick-up function”を仮 定し, 正弦波やStokes 波のもとでの濃度の時間変化を 求めている. 彼は振動流境界層の特性を放出される渦に よって表現して解析している．波によって底面に発達す る層流境界層あるいは乱流境界層の底面近傍での流速は 境界層外縁の流速に比べ $\pi / 4^{11)}$ あるいは $\pi / 8^{12)}$ 位相がず れることが明らかにされていることを考えれば，底質の 移動を論ずる際には底面に発達する境界層を考慮した流 れの詳細な挙動を把握することが重要となる。

従来, 境界層内の流速は境界層外縁における境界条件 として微小振幅波理論から算出した流速を用いて解析さ れてきた. Bakker・van Doorn ${ }^{13)}$ や浅野・岩垣 ${ }^{14)}$ は, 非 線形波動下における乱流境界層内の流速の解析におい て，境界層外縁における境界条件としてそれぞれ実測の 流速波形や Stokes 波の第 2 次近似解加算出した流速 を用いている.こうした研究では, 底面近傍の摩擦応力 を，時間的に一定でかつ鉛直方向に一定あるいは線形で 
ある渦動粘性係数を用いて評価するか, もしくは Prandtl の混合距離理論で評価している.なお，乱流モ デルによる砂漣上の振動流境界層流れの解析も行われて いる16).

堀川・渡辺 ${ }^{16)}$ は滑面, 粗面床上での境界層内の流速の 測定値に基づいて渦動粘性係数を算出し, 渦動粘性係数 は時間的に変動することを得ている. Trowbridge・ Madsen ${ }^{17)}$ は境界層外縁における流速として Stokes 波の 第 2 次近似解を与え, 時間的に一定あるいは変動する渦 動粘性係数を用いた解析を行って van Doorn ${ }^{18)}$ の実験結 果と比較したところ，時間的に変動する渦動粘性係数に よる解析結果が実験結果をよく説明することを得，さら に時間的に変動する渦動粘性係数は質量輸送を決定する 際には重要であることを示唆している.

このように, 波動場における浮遊砂の挙動を適切に把 握しそれに基づいて底質輸送の問題を解明してゆくため には，底面近傍に発達する乱流境界層を考慮し場所的あ るいは時間的に変動する渦動粘性係数や乱流拡散係数を 用いた解析を行うとともに，種々の観測結果や実験結果 との比較を通してこうしたモデルの妥当性の検討を行う ことはきわめて重要であると思われる。しかしながら，

こうした問題に関する従来の研究では乱流拡散現象を支 配する主要因の 1 つである乱流拡散係数は時間的に一定 でかつ鉛直方向に一定あるいは線形であるとして解析す るのが大勢である.

こうしたことから，本論文ではまず時間的に一定で鉛 直方向に変化する渦動粘性係数や時間的・場所的に変動 する渦動粘性係数を用いて摩擦応力を評価すると同時に Prandtl の混合距離理論によっても評価し乱流境界層内 の流速を計算する．次に，この流速を用いて Kalkanis ${ }^{19)}$ の理論を援用して底面での濃度を評価し，時間的に一定 で鉛直方向に変化する乱流拡散係数や時間的・場所的に 変動する乱流拡散係数を用いて流体中の濃度を求め, 柿 沼・伊福ら ${ }^{20)}$ が観測で得た平均濃度, 流速と濃度の位相 差を理論的に説明する.また，野田 ${ }^{3)}$ が大潟海岸の砕波 帯外で得た観測結果，Nielsen ${ }^{21)}$ が砕波帯内で得た観測 結果, Deigaard ら ${ }^{22)}$ が水槽実験で得た結果に基づいて 同様な解析を行う.さらに, 解析して得た流速と流体中 の物質の濃度から漂砂量を算出し, その時間変化や移動 方向について検討する.

\section{2. 観測資料および実験資料}

柿沼・伊福ら ${ }^{20)}$ は 1983 年と 1984 年の冬期季節風時, 愛媛県松山市の梅津寺海岸の平均水深 $2 \mathrm{~m}$ 亡 $1.7 \mathrm{~m}$ の 地点の海底加 7, 65, $98 \mathrm{~cm}$ と $31,45,75 \mathrm{~cm}$ の高さ に 2 成分が測定可能な電磁誘導型流速計 3 台 (うち 1 台 圧力計内蔵), 海底加ら $4 \mathrm{~cm}$ (1983 年) と $30 \mathrm{~cm}$ (1984 年)
の高さに散乱光式濁度計を設置し，岸沖-沿岸方向流速 と岸沖-鉛直方向流速, 圧力変動と浮遊砂濃度の記録を 得た. 観測時の水深は $0.93 \sim 3.41 \mathrm{~m}$ ，有義波高は 0.33 $\sim 0.80 \mathrm{~m}$, 有義波周期は $4.4 \sim 5.3 \mathrm{~s}$, 浮遊砂濃度は 50 〜 $808 \mathrm{mg} / l$, 砕波の発生頻度は 4 25\%, 観測点付近の 底質の中央粒径は $0.18 \mathrm{~mm}$ であった。なお，両年とも 砕波形式は目視観測によると spilling 型であった.

Nielsen ${ }^{21)}$ はオーストラリアの 4 つの海岸の砕波帯に おいて海底から $45 \mathrm{~cm}$ の高さに圧力計, $30,70 \mathrm{~cm}$ の高 さにプロペラ式流速計，1.5～60 cm の高さに 7 個の取 入れ口をもつボスマン型サンプラーを海底に設置し, 圧 力変動, 岸沖方向流速と浮遊砂濃度の記録を得ている. 観測時の水深は $0.94 \sim 1.80 \mathrm{~m}$, 有義波高は $0.33 \sim 0.78$ $\mathrm{m}$, 有義波周期は $7.1 \sim 14.4 \mathrm{~s}$, 浮遊砂濃度は $2 \sim 5900$ $\mathrm{mg} / l$, 観測点付近の底質の中央粒径は $0.12 \sim 0.22 \mathrm{~mm}$, 水温は $21 \sim 26^{\circ} \mathrm{C}$ であった.

野田 ${ }^{3)}$ は大潟海岸の平均水深 $6 \mathrm{~m}$ の地点で波浪を観測 するとともに海底から 0.5 5 $\mathrm{m}$ の高さで竹竿式捕砂器 によって浮遊砂を採集している. 得た有義波高は $1.0 \mathrm{~m}$, 有義波周期は $6.0 \mathrm{~s}$, 浮遊砂濃度は $240 \sim 800 \mathrm{mg} / l$, 浮 遊砂の中央粒径は $0.3 \mathrm{~mm}$ であった。

Deigaard $ら^{22)}$ は水深 $0.27 \sim 0.38 \mathrm{~m}$, 波高 $0.1 \sim 0.14$ $\mathrm{m}$, 周期 $1.4 \sim 2.1 \mathrm{~s}$, 中央粒径 $0.12 \mathrm{~mm}$ の砂を用いた 水槽実験によって，底面から $0.7 \sim 9 \mathrm{~cm}$ の高さで 300 $4000 \mathrm{mg} / l$ の浮遊砂濃度の記録を得ている.

\section{3. 乱流境界層理論，乱流拡散理論に基づく浮 遊砂濃度分布の解析方法}

\section{（1）基礎方程式}

流体が非圧縮で，その運動が非定常な場合の鉛直一次 元境界層方程式は， $x$ 軸を水平な底面にとり， $z$ 軸を底 面より鉛直上向きにとると，次式で与えられる.

$$
\frac{\partial\left(u-u_{b}\right)}{\partial t}=\frac{1}{\rho_{f}} \frac{\partial \tau}{\partial z}
$$

ここに, $t$ は時間, $\rho_{f}$ は流体の密度， $\tau$ は摩擦応力, $u$ および $u_{b}$ は境界層内および境界層外縁における $x$ 方向 の流速成分である.

沈降速度 $w_{0}$ をもつ物質の鉛直一次元の乱流拡散方程 式は次式のように与えられる.

$$
\frac{\partial C}{\partial t}+w \frac{\partial C}{\partial z}=\frac{\partial}{\partial z}\left(K_{z} \frac{\partial C}{\partial z}\right)+w_{0} \frac{\partial C}{\partial z}
$$

ここに, $C$ は物質の濃度, $w$ は $z$ 方向の流速成分, $K_{z}$ は乱流拡散係数である。

\section{（2）初期条件および境界条件}

$u(=u(z, t))$ に関する初期条件および境界条件は

$u(z, 0)=0$ 


$$
\left.\begin{array}{ll}
u\left(z_{0},\right. & t)=0 \\
u\left(\delta_{b},\right. & t)=u_{b}(t)
\end{array}\right\}
$$

とする.ここに， $z_{0}$ は粗度長， $\delta_{b}$ は境界層厚である.

$C(=C(z, t))$ に関する初期条件および境界条件は

$C(z, 0)=0$

$$
C\left(\delta_{B}, t\right)=C_{0}(t)
$$$$
K_{z} \frac{\partial C}{\partial z}+w_{0} C=0, z=h
$$

とする.ここに， $\delta_{B}$ は掃流層厚， $C_{0}(t)$ は時刻 $t$ にお ける掃流層内の濃度, $h$ は水深である.

\section{（3）境界層内の流速}

摩擦応力, 粗度長, 境界層厚を以下のように定め境界 層内の流速を求める.

摩擦応力：境界層外縁の最大流速あるいは境界層外縁 の流速に依存する渦動粘性係数 $N_{z}(z)$ あるいは $N_{z}(z$,

$t$ ）を用いると次のように表わせる.

$$
\begin{aligned}
& \tau=\rho_{f} N_{z}(z) \frac{\partial u}{\partial z} \cdots \\
& \tau=\rho_{f} N_{z}(z, t) \frac{\partial u}{\partial z}
\end{aligned}
$$

ここに, $N_{z}(z)=\alpha \varkappa \sqrt{f} u_{b m} z$ （ $\alpha$ : 比例定数, $x$ : カルマ ン定数, $f$ : 海底摩擦係数, $u_{b m}$ : 境界層外縁の最大流 速), $N_{z}(z, t)=\alpha x \sqrt{f}\left|u_{b}(t)\right| z$ である.

浮遊物質が存在する場合のカルマン定数の変化に関す る経験式 ${ }^{23), 24)}$ はあるがこれらはいずれも一方向流に対す るものであり，波に対するこうした経験式は著者らの知 り得る限りでは提案されていないようである.ここでは カルマン定数の值は浮遊物質が存在しない場合の值 0.4 を用いることにする. 海底摩擦係数は柿沼・伊福の経験 式年を用いて求める.

Prandtl の混合距離理論によれば摩擦応力は次のよう に表わせる.

$$
\tau=\rho_{f} l^{2} \frac{\partial u}{\partial z}\left|\frac{\partial u}{\partial z}\right|
$$

ここに, $l$ は混合距離 $(l=x z)$ である.

境界層厚 : 野田 ${ }^{26)}$ が微小振幅波による乱流境界層内の 流速分布の解析で得た結果を援用し

$\delta_{b}=25 \delta$

とする.ここに, $\delta=\sqrt{\nu T / 2 \pi}$ であり, $\nu$ は流体の動粘 性係数, $T$ は波の周期である.

粗度長：Bakker・van Doorn ${ }^{27)}$ に従い砂漣の高さの $1 / 33$ 倍とし, 砂漸の高さは Nielsen の経験式 ${ }^{28)}$ を用い て算出する.

\section{(4) 濃度}

掃流層内の濃度, 乱流拡散係数, 沈降速度を以下のよ うに定め流体中における物質の濃度を求める.

掃流層内の濃度 : 底面に均一粒径の物質が一様に分布 していると仮定したとき, Kalkanis の理論によれば掃
流層内の濃度は

$$
C_{0}=2 P \rho_{s}^{\prime} d V / 3 \int_{z_{0}}^{\sigma_{B}} u d z
$$

で与えられる。ここに, $\rho_{s}^{\prime}$ は乾燥物質の密度, $d$ は物 質の粒径, $V$ は物質の移動速度, $P$ は pick-up function であり，次式で与えられる。

$$
P=\frac{1}{\sqrt{2 \pi}} \int_{B * \mathbf{I}^{\prime}-1 / \eta_{0}}^{\infty} \exp \left(-z^{2} / 2\right) d z
$$

ここに, $B_{*}=4 / 3 C_{L} \eta_{0}$ ( $C_{L}$ : 揚力係数, $1 / \eta_{0}$ : 経験定数), $\Psi^{\prime}=\left(\rho_{s}-\rho_{f}\right) g d / \rho_{f} u_{0}^{2} \quad\left(\rho_{s}:\right.$ 物質の密度 $\left(\rho_{s}=n \rho_{f}+\right.$ $(1-n) \rho_{s}^{\prime}, n$ : 間隙率), $u_{0}$ : 任意の高さにおける流速,

$g:$ 重力の加速度) である.

式（９）の物質の移動速度をいかに評価するかが問題 となるが，ここでは掃流層内の断面平均流速に等しいと 仮定する.

乱流拡散係数：境界層外縁の最大流速あるいは境界層 外縁流速に比例する 2 つ場合と水平方向および鉛直方 向の流速成分に依存する場合の 3 通りを仮定する.

$$
\begin{aligned}
& K_{z}=\beta \alpha \varkappa \sqrt{f} u_{b m} z \cdots \\
& K_{z}=\beta \alpha \varkappa \sqrt{f}\left|u_{b}(t)\right| z \\
& K_{z}=\gamma\left(l_{T} u^{2}+l_{L} w^{2}\right) / q
\end{aligned}
$$

ここに, $\beta, \gamma$ は比例定数, $l_{T}, l_{L}$ は水平および鉛直方 向流速成分による拡散係数への寄与を表わす特性長であ り, $l_{L}=a l_{T}$ ( $a$ : 比例定数 $), q=\left(u^{2}+w^{2}\right)^{1 / 2}$ である. 式 $(11 \cdot c)$ は多孔質体内における物質の分散について Scheidegger ${ }^{29)}$ によって見出された式と同形のものを仮 定した。

物質の沈降速度：次式 ${ }^{30)}$ で算出する.

$$
w_{0}=\sqrt{\frac{4}{3} \frac{d}{C_{D}} \frac{\rho_{s}^{\prime}-\rho_{f}}{\rho_{f}} g}
$$

ここに, $C_{D}$ は抗力係数であり, Reynolds 数 $R e=$ $w_{0} d / \nu$ が 5 より小さい場合, 次式で与えられる ${ }^{31)}$.

$$
C_{D}=\frac{24}{R e}+4.5
$$

\section{（5）数值解析法}

差分法を用いて境界層内の流速に関する式（1）と物 質の濃度に関する式 (2) の解を得る. 計算にはクラン クーニコルスン法を用い鈶直座標および時間を以下のよ うに分割する.

鉛直座標：底面から水面までを 100 分割し, 底面から 物質の粒径の 3 倍の高さまでを粒径の $1 / 2$ の等間隔, そ れより水面までを等比級数的に分割する.

時間：波の 1 周期を 96 等分する.

境界層内の流速は境界層内の各高さ, 濃度は各高さに おいて，任意の時刻 $m T(m$ : 整数 $)$ と 1 周期前 $(m$ -1) T の流速あるいは濃度との差の絶対值が $10^{-5}$ 以下 になるまで計算を行い, それ以後は求めた值が 1 周期ご 


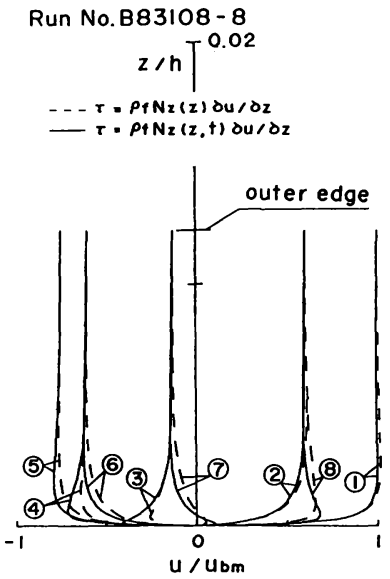

(a)

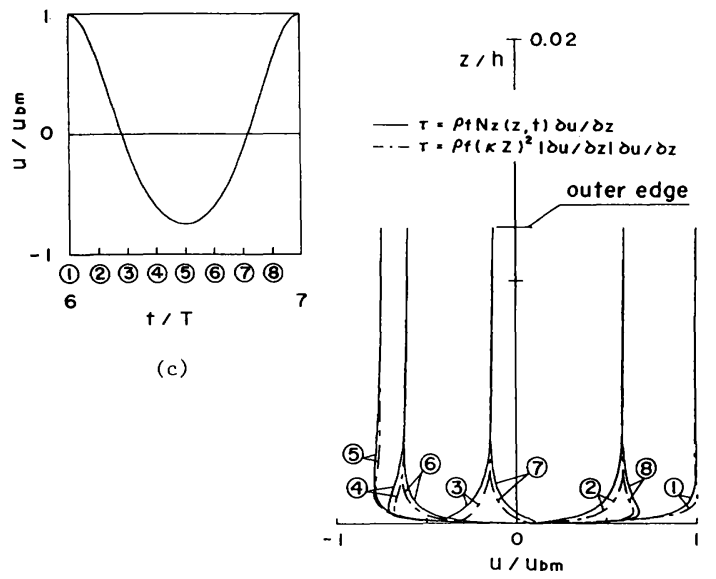

(b)

Fig. 1 Velocity distributions in the turbulent boundary layer.

\section{とに繰り返すものとする。}

対象とする流体は柿沼・伊福ら, Nielsen および野田 の資料では海水, Deigaard らの資料では淡水とするが, 梅津寺海岸での水温は観測海岸から $1 \mathrm{~km}$ 程度離れた松 山市高浜港沖における 1983 年 1 月 3 月の水面近傍の 平均水温 $10^{\circ} \mathrm{C}^{32)}$, Nielsen が観測した海岸での水温は $21 \sim 26^{\circ} \mathrm{C}$ であることから $20^{\circ} \mathrm{C}$ ，野田の観測資料および

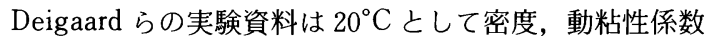
を算出する. 対象とする物質は砂とし, 粒径は梅津寺海 岸では $0.18 \mathrm{~mm}$, Nielsen が観測した海岸では観測して 得た値 $0.12 \sim 0.22 \mathrm{~mm}$ ，野田が観測した大潟海岸では 観測して得た值 $0.3 \mathrm{~mm}$, Deigaard らは実験で用いた值 $0.12 \mathrm{~mm}$, 乾燥砂の密度は $2.65 \mathrm{~g} / \mathrm{cm}^{3}$, 間隙率は 0.3 と する.

\section{4. 解析結果}

現地観測で得た平均水深，有義波高，有義波周期，底 質粒径および室内実験で用いた水深，波高，周期，底質 粒径をもとにパラメータ一解析を行った．有義波は，梅 津寺海岸ではStokes 波の第 3 次近似解, Nielsen が観 測した海岸ではクノイド波理論，野田が観測した大潟海 岸ではStokes 波の第 2 次近似解および Deigaard らが 実験で用いた波はStokes 波の第 3 次近似解が適用され る領域にある ${ }^{33)}$.

Einstein・El-Samni ${ }^{34)}$ は一方向流の底面近傍での圧力 測定から揚力係数の值は 0.178 であることを得ている. ここでは式（10）中の揚力係数は $0.2 ， 1 / \eta_{0}$ は Kalkanis が実験で得た $1.5 ， u_{0}$ は砂粒頂部での值とする．掃 流層厚はEinstein ${ }^{35)}$ を援用し粒径の 2 倍とする。式 $(11 \cdot \mathrm{c})$ 中の特性長 $l_{T}$ および $l_{L}$ をいかに評価するかが 問題となるが，本論文では $l_{T}$ を底面からの高さと仮定
して解析する.

\section{（1）流速}

a）境界層内の流速分布

梅津寺海岸における資料 No. B 83108-8 (水深 2.15 m, 有義波高 $0.53 \mathrm{~m}$, 有義波周期 $4.5 \mathrm{~s}$ ）に基ついて計算し た境界層内の流速分布を境界層外縁の流速の時間波形と ともに示したのが Fig. 1 である.（a)，(b) は境界層内 の流速分布で, 実線は摩擦応力を式 $(7 \cdot b)$, 一点鎖線 は式 $(7 \cdot \mathrm{c})$ ，破線は式 $(7 \cdot a)$ で評価したものである. (c) に境界層外緣流速の時間波形を示す。（a）によると境界 層外縁流速が正でかつ減速時の位相となる(1)，(2)では実 線と破線はほぼ同一の分布をしているが，他の位相では 実線で示される流速が大きめであり，特に位相(4)，(8)で over-shooting 現象が顕著である.（b）によると位相(1), (2), 6)，(7)で相対高さが 0.002 付近において実線で示さ れる流速は一点鎖線で示される流速よりもわずかに小さ いが，境界層外縁流速の絶対値が最大となる位相(5)では ほぼ同一の分布を示す.式 $(7 \cdot b)$ および式 $(7 \cdot c)$ で 摩擦応力を評価した流速分布はわずかな違いはあるもの のよく似た傾向をしているようである.なお，この際の $\alpha$ の值は 0.1 であった.

b）砂粒頂部の流速波形

摩擦応力の評価の違いによる砂粒頂部での流速波形を 示したのがFig. 2 であり，実線は式 $(7 \cdot b)$ ，一点鎖線 は式 $(7 \cdot \mathrm{c})$, 点線は式 $(7 \cdot \mathrm{a})$ によっている，前二者は 岸向き流速（正）と沖向き流速（負）の最大值がほぼ同 一であり,岸向き流速の最大值は同位相で生じているが, 沖向き流速の最大值が生ずる位相は式 $(7 \cdot b)$ による場 合の方が $0.2 \pi$ 程度早い. 時間に依存しない渦動粘性係 数による場合は式 $(7 \cdot \mathrm{c})$ による場合と同一の傾向を示 すがわずかに小さい，3 ケースとも波形は前後・上下非 


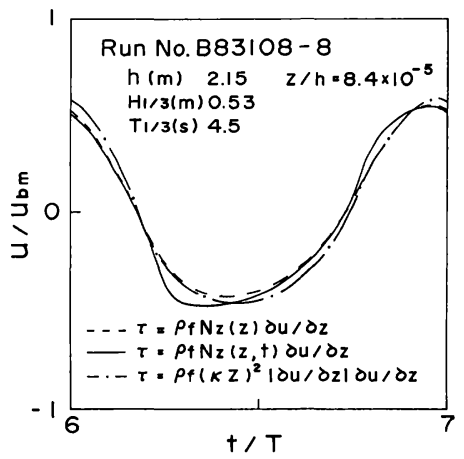

Fig. 2 Temporal variations of water particle velocity at the top of sand particle.

対称であるがその度合いは式 $(7 \cdot b)$ による場合が最も 大きい．この流速の非対称性は掃流層内の濃度, 漂砂量 やその移動方向に影響すると考えられる.

\section{(2) 濃度}

a) 掃流層の濃度

各時刻における掃流層内の濃度 $C_{0} / \rho_{s}^{\prime}$ と $1 / \Psi^{\prime}$ との関 係を Fig. 3 に示す. $1 / \Psi^{\prime}$ が増大するにつれて掃流層の 濃度は増大しほぼ 0.3 に漸近するようである。この結果

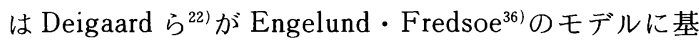
づいて底面濃度を算出した結果とよく似た傾向を示す。

\section{b）平均濃度の鉛直分布}

1983 年に得た資料（Run No. B 83108-8）に基づいて 算出した平均濃度の鉛直分布を，その資料およびそれと 波浪特性がほぼ同一である 1984 年に得た資料（Run No. B 84317-5）の平均濃度の観測值（黒丸および白丸） とともに示したのが Fig. 4 である．実線および点線は摩 擦応力を式 $(7 \cdot b)$, 乱流拡散係数を式 $(11 \cdot c)$ および $(11 \cdot b)$ で評価した場合であり，破線は渦動粘性係数， 乱流拡散係数とも時間に依存しない場合である. 三者と も底面近傍で濃度変化が大きく「く」の字形の分布を示 すが, 底面からの距離が大きくなるにつれてそれらの間 の濃度の差が大きくなる．点線と破線については両者の 間にわずかな違いはあるもののほぼ同一の傾向を示し 4 $\mathrm{cm}$ の高さでの観測結果をよく説明するようであるが, $30 \mathrm{~cm}$ の高さでは観測結果よりそれぞれ $65 \mathrm{mg} / l$ および $50 \mathrm{mg} / \mathrm{l}$ 程度小さい．水平方向と鉛直方向の流速成分に 依存する乱流拡散係数を用いて得た実線については，30 $\mathrm{cm}$ の高さでは観測結果よりわずかに小さいが観測結果 をよく説明する．ただ，式 $(11 \cdot a)$ および式 $(11 \cdot b)$ 中の比例定数 $\beta$ の值を大きくすれば, 底面から離れた 高さでの濃度を説明することは可能であるが，底面近傍 の濃度, ひいては漂砂量を過大に見積ることになる．そ こで,ここでは底面近傍の濃度をうまく説明する $\beta$ の 値を採用した。

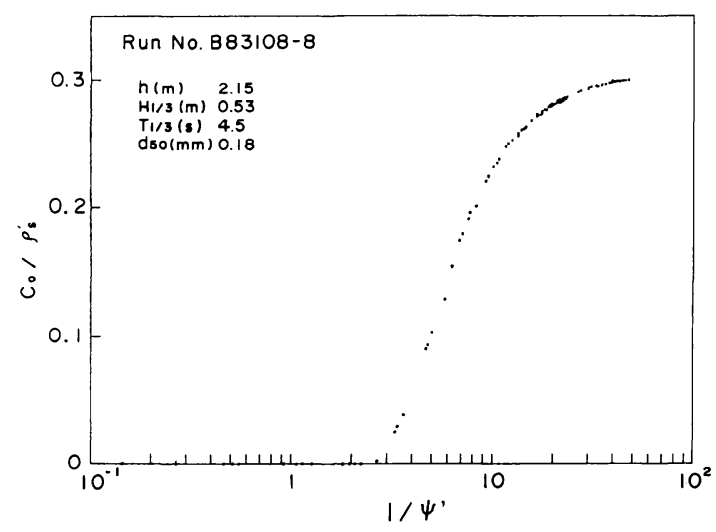

Fig. 3 Concentration in the bed-load layer as a function of $1 / \Psi^{\prime}$.

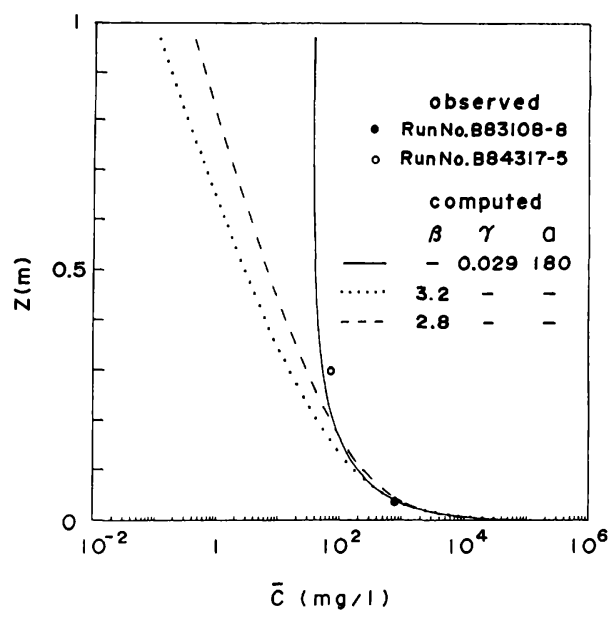

Fig. 4 Distributions of mean suspended sediment concentration.

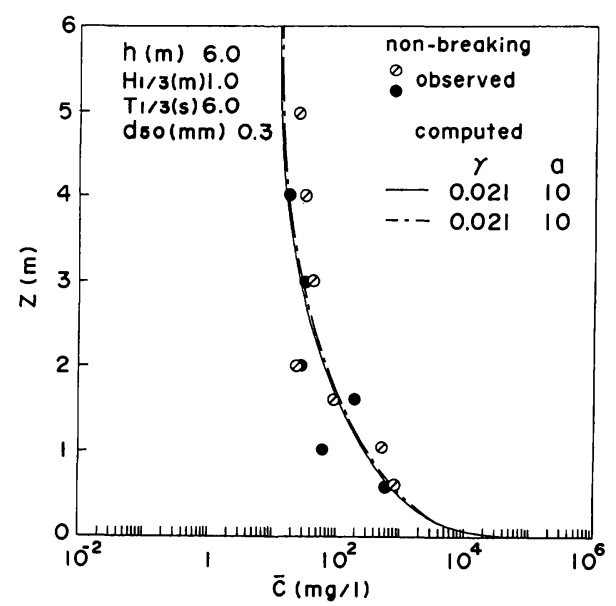

Fig. 5 Distributions of mean suspended sediment concentration; $(\bigcirc, \oslash)$ : after Noda ${ }^{3}$. 


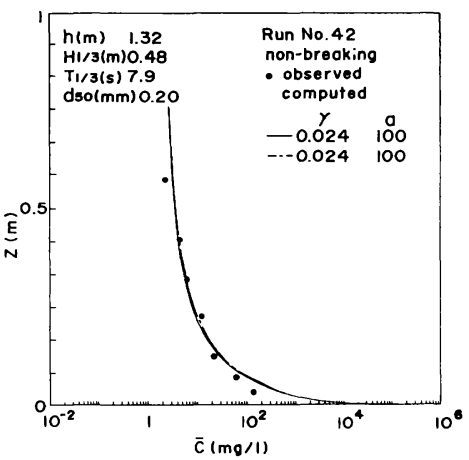

(a) non-breaking

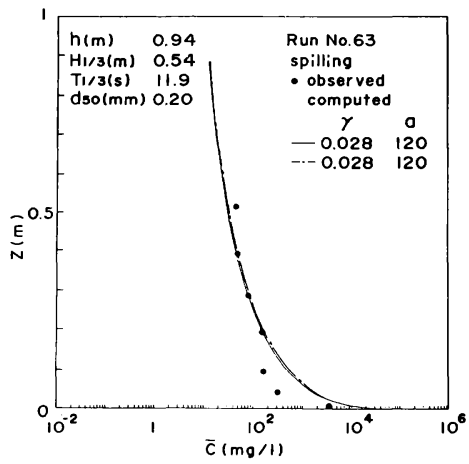

(b) spilling breaker

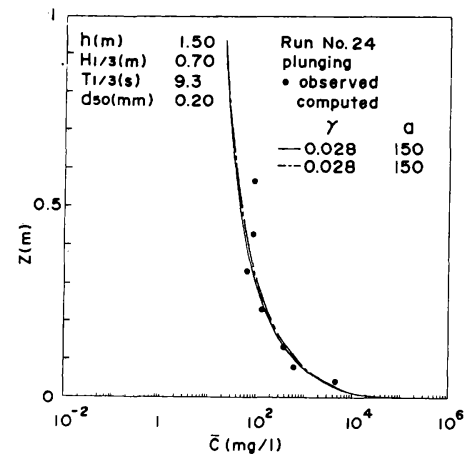

(c) plunging breaker

Fig. 6 Distributions of mean suspended sediment concentration; (O): after Nielsen ${ }^{21)}$.

Fig. 5 は野田 ${ }^{3)}$ の観測結果に基づいて計算した平均濃 度の鉛直分布を観測結果とともに示す．観測した波は非 砕波である．図中の実線および一点鎖線はそれぞれ摩擦 応力を式 $(7 \cdot b)$ および式 $(7 \cdot c)$ で評価し, 乱流拡散 係数は式 $(11 \cdot c)$ を用いており, 式 $(7 \cdot b)$ 中の $\alpha$ の值 は 0.1 とした. 各高さでの平均濃度は摩擦応力を渦動粘 性係数を用いて評価した場合 (式 $(7 \cdot b))$ とPrandtl の 混合距離理論で評価した場合（式 $(7 \cdot c))$ の両者はよく 一致し，観測結果をかなりうまく再現している.

Fig. 6 は Nielsen ${ }^{21)}$ の観測結果に基づいて解析した 14 例中の代表的な 3 例の平均濃度の鉛直分布を示したもの で，(a)，(b) および（c）はそれぞれ非砕波， spilling 型砕波および plunging 型砕波である. 図中の実線およ び一点鎖線は摩擦応力を式 $(7 \cdot \mathrm{b})$ および式 $(7 \cdot \mathrm{c})$ で 評価し, 式 $(7 \cdot b)$ 中の $\alpha$ の值は 0.1 とした. 乱流拡散 係数は式 $(11 \cdot \mathrm{c})$ を用いており，式中の比例定数 $\gamma$ お よび $a$ は観測結果と計算結果の差が最も小さいものを 採用した（a）によれば計算結果は底面近傍で観測結果 より大きめであるが，底面から $50 \mathrm{~cm}$ より上方では小 さめである. (b) によれば解析結果は底面近傍で観測 結果より大きめであるが，底面から $30 \mathrm{~cm}$ より上方で は観測結果とよく一致している. (c) によれば計算結果 は spilling 型砕波に比べて底面付近でも観測結果をよく 説明する.

\section{c）流速と濃度の位相差}

梅津寺海岸において観測して得た岸向き流速と濃度の 位相差の頻度分布を，計算して得た海底から $4 \mathrm{~cm}$ の高 さでの濃度の時間変化とともに示したのが Fig. 7であ る. 砕波の発生頻度は（a）が $13 \% ，(b)$ が $19 \%$ であ る.計算結果の平均濃度の鉛直分布は観測結果とほぼ同 一であり, 実線と点線は式 $(7 \cdot b)$ 中の比例定数 $\alpha$ の值 を 0.1 とし, 乱流拡散係数を式 $(11 \cdot c)$ と式 $(11 \cdot b)$ で評価した場合，一点鎖線は摩擦応力を式 $(7 \cdot c)$, 乱流
拡散係数を式 $(11 \cdot c)$ で評価した場合であり，破線は渦 動粘性係数，乱流拡散係数とも時間に依存しない場合で ある. 渦動粘性係数，乱流拡散係数とも時間に依存しな い場合（破線）は，観測して得た位相差の頻度分布が高 い值を示す位相 $\pi / 2,(1.1 \sim 1.3) \pi$ 付近で濃度はピーク を示すが，両ピークの值はほぼ同一である。一方，式 $(7 \cdot b)$ あるいは式 $(7 \cdot c)$ で摩擦応力を評価しかつ時 間に依存する乱流拡散係数を用いた場合（実線, 点線, 一点鎖線) には, 頻度分布が高い值を示す位相 $\pi / 2,(1.1$ 〜1.3) $\pi$ 付近で第 1 ピークと第 2 ピークを示し, 観測で 得た位相差の頻度分布ともよく対応する.しかしながら， （a）においては実線，点線と一点鎖線はほぼ似た変動を しているが，(b) において位相差の頻度分布が小さい 值を示す $4 / 5 \pi$ 付近では実線および一点鎖線すなわち乱 流拡散係数が水平方向および鉛直方向の流速成分に依存 するものの方が観測で得た位相差の頻度分布をよく説明 するようである.

\section{（3）乱流拡散係数}

野田 ${ }^{3)}$ および Nielsen ${ }^{211}$ が観測して得た平均濃度分布 をうまく説明する式 $(11 \cdot c)$ による乱流拡散係数の無次 元量と相対高さとの関係を Fig. 8 に示す. (a) は野田の 観測結果に基づくもの，(b) および（c）はNielsen の 観測結果に基づくものでそれぞれ spilling 型砕波および plunging 型碎波のものである. 図中の実線は $t / T$ が 6 , $6.25 ， 6.5 ， 6.75$ におけるもの，破線は 1 周期平均の值， 図中の記号は観測して得た平均濃度の鉛直分布から次式 を用いて算出したものである。

$$
\overline{K_{z}}=-w_{0} \bar{C} /(\partial \bar{C} / \partial z) \cdot
$$

解析に用いた乱流拡散係数の 1 周期平均值 (破線) は (a) では相対高さがほぼ 0.2 付近，(b) と（c）では 0.07 付近まで相対高さのほぼ 1 乗に比例するがそれより水面 までは 2 乗に比例する.

ところで, Fig.4においてみられたように, 時間に依 


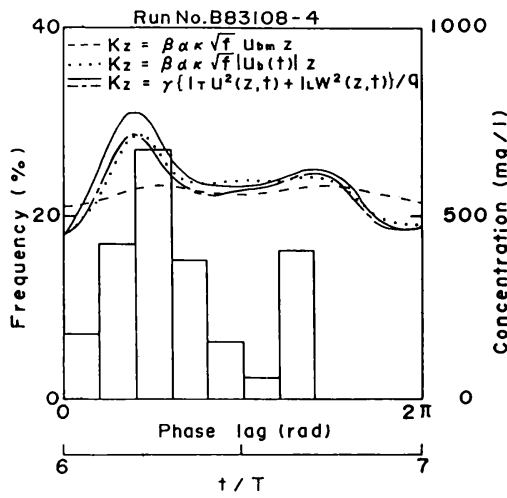

(a)

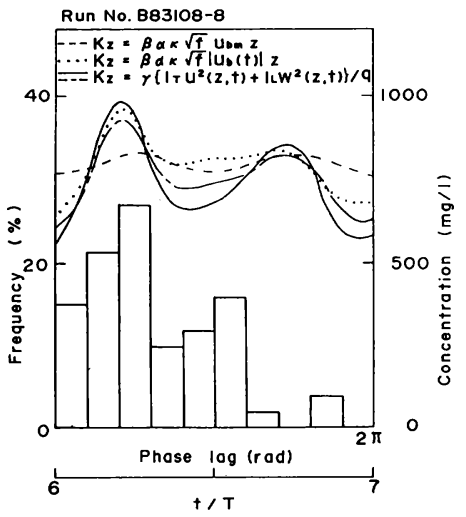

(b)

Fig. 7 Computed temporal variations of suspended sediment concentration and histogram of phase lag between maximum cross-shore velocity and maximum concentration in a wave cycle ; the frequencies of breaker occurrence are (a) $13 \%$ and (b) $19 \%$.

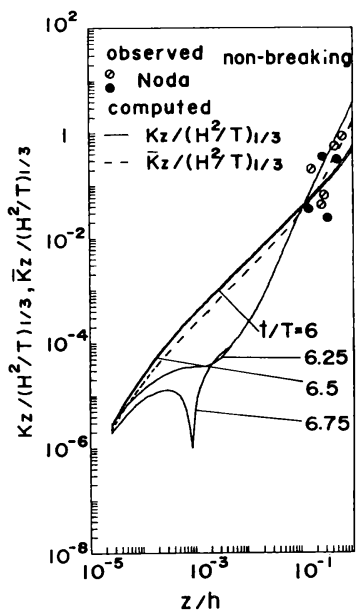

(a) non-breaking

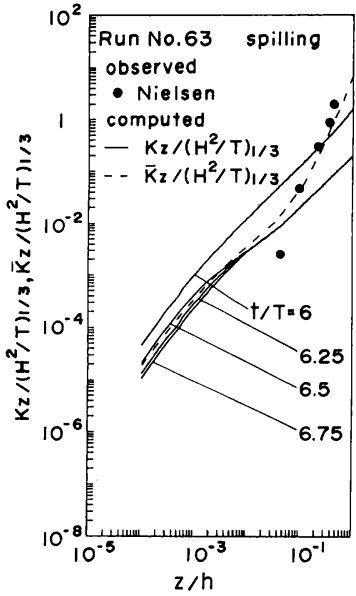

(b) spilling breaker

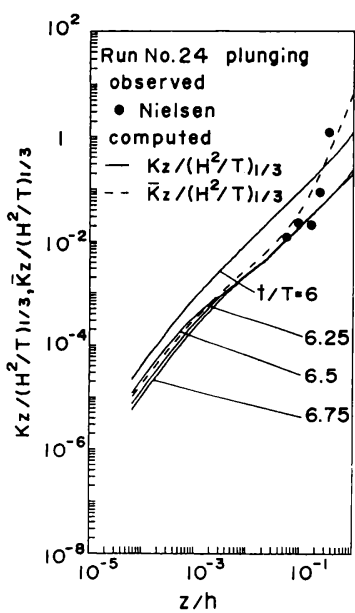

(c) plunging breaker

Fig. 8 Nondimensional turbulent diffusion coefficient as a function of relative height.

存しない乱流拡散係数あるいは水平方向の流速成分にの み依存する乱流拡散係数では底面から $30 \mathrm{~cm}$ 程度離れ た高さでの濃度をよく説明できなかった. Deigaard ら は砕波によって生成される乱れエネルギーを考慮し，エ ネルギー輸送方程式に基づいた流速場の解析をもとに流 体中の浮遊砂濃度分布を求め Nielsen の観測結果と比較 している. 彼らの解析は定量的な評価にまでは至ってい ないが, 波動場における乱流拡散現象を解明するには水 面近傍では水平方向のみならず鉛直方向の運動をも考慮 する必要があることを示唆するものではないかと思え る. 以上のことから, 式 $(11 \cdot \mathrm{c})$ で評価する乱流拡散係 数は式中の比例定数 $\gamma$ や $a$ を波浪の状況に応じて見積 ることにより波動場における乱流拡散現象をうまく説明 できるものと考える.

\section{（4）比例定数 $\gamma, \boldsymbol{a}$ と波浪および底質との関係}

野田，柿沼・伊福らと Nielsen の観測結果および Deigaard らの実験結果をよく説明する式 $(11 \cdot \mathrm{c})$ 中の 特性長の比 $a$ はそれぞれ 10，120～180 と 100～150 お よび 20 であった. 一方, 得た $\gamma$ について $H_{1 / 3} / d_{50}$ との 関係をみるとFig.9 のようになる. 野田と Deigaard ら および Nielsenの非砕波, Nielsen の plunging 型, 柿 沼・伊福らと Nielsen の spilling 型のものは $H_{1 / 3} / d_{50}$ が大きくなるにつれて $\gamma$ の值は小さくなり負の相関が ある. 同一の $H_{1 / 3} / d_{50}$ については plunging 型, spilling 型, 非砕波の順に $\gamma$ の值は小さい.このことは, plunging 型砕波は spilling 型砕波や非砕波に比べて波 が砕ける際に波の前面が水中に突っ込みその影響が底面 近傍にまで及ぶために拡散が大きくなり, 浮遊物質を水 


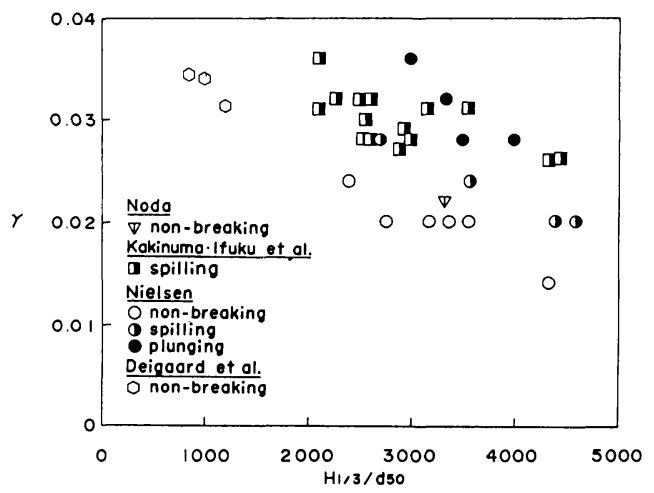

Fig. 9 Proportional constant $\gamma$ as a function of the ratio of significant wave height to median diameter of sand.

面近傍まで巻き上げることを説明するものではないかと 考える. 式 $(11 \cdot \mathrm{c})$ 中の比例定数 $a$ 之波高水深比との 間には波高水深比が増大するにつれて比例定数 $a$ は増 大する傾向があり，波高水深比が大きいほど乱流拡散係 数に及ぼす鉛直方向の流速成分の影響が重要となること がわかる。

\section{（5）漂 砂 量}

時刻 $t$ における粗度長の高さから掃流層外縁までの 掃流漂砂量を $q_{B}(t)$, 掃流層外縁から境界層外縁までの 浮遊漂砂量を $q_{s}(t)$, 粗度長の高さから水面 $h$ までの全 漂砂量を $q(t)$ として，それぞれ次式で算出する。なお， 境界層外縁および境界層外の流速はポテンシャル理論に よって算出した.

$$
\begin{aligned}
& q_{B}(t)=\int_{z_{0}}^{\delta_{B}} C u d z \\
& q_{s}(t)=\int_{\delta_{B}}^{\delta_{b}} C u d z \\
& q(t)=\int_{z_{0}}^{h} C u d z
\end{aligned}
$$

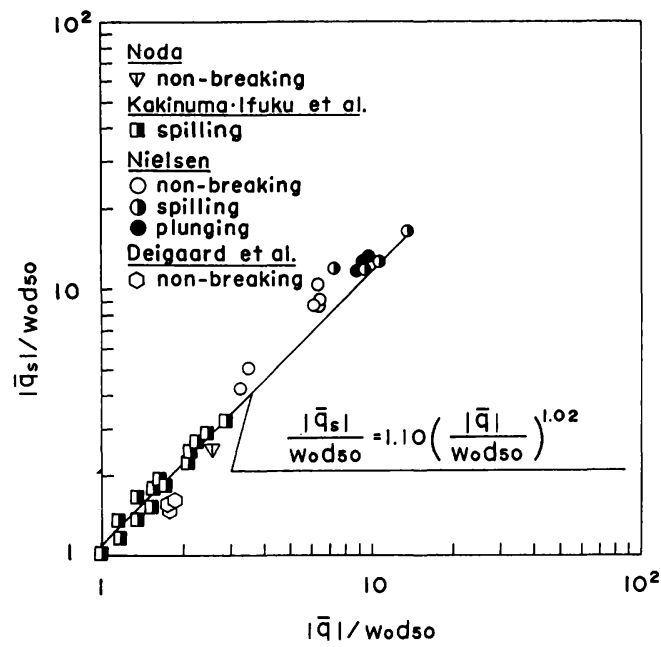

Fig. 10 Nondimensional suspended and net transport rates a) 無次元浮遊漂砂量 $\left|\bar{q}_{s}\right| / w_{0} d_{50}$ と無次元全漂砂量 $|\bar{q}| / w_{0} d_{50}$

摩擦応力を式 $(7 \cdot b)$ で評価して乱流境界層内の流速 を求めた場合の 1 周期平均した無次元浮遊漂砂量と無次 元全漂砂量との関係を Fig. 10 に示す. 図中の実線は最 小二乗法で求めた回帰式である. 波の 1 周期で平均した 漂砂量は 0 ではなくその移動方向は Deigaard らの実験 結果に基づく解析結果を除けば岸向きである．無次元全 漂砂量は無次元浮遊漂砂量とほぼ等しく，漂砂の移動様 式は浮遊漂砂が卓越する．漂砂量は底面近傍に形成され る境界層内でそのほとんどが決定されることから，漂砂 量を算出する場合波によって底面近傍に発達する境界層 の取扱いが重要となる。

b) 摩擦応力の評価の違いによる漂砂量の差

摩擦応力を渦動粘性係数を用いて評価した場合の 1 周 期平均の無次元全漂砂量 $\left(|\bar{q}| / w_{0} d_{50}\right)_{e}$ と Prandtl の混 合距離理論に基づいて評価した場合の 1 周期平均の無次 元全漂砂量 $\left(\bar{q} / w_{0} d_{50}\right)_{p}$ との関係を Fig. 11 に示す. 図 中の実線は最小二乗法で求めた回帰式である.なお，式 $(11 \cdot c)$ 中の比例定数 $\gamma$ および $a$ は同一の值を用いた. 野田，柿沼・伊福らおよび Nielsen の観測結果に基づい て得た 1 周期平均の全漂砂量の移動方向は摩擦応力を渦 動粘性係数を用いて評価した場合および Prandtl の混合 距離理論に基づいて評価した場合とも岸向きであるが, Deigaard らの実験結果に基づいて得た 1 周期平均の全 漂砂量の移動方向は摩擦応力を渦動粘性係数を用いて評 価した場合は沖向き，Prandtl の混合距離理論に基づい て評価した場合は岸向きである．Deigaard らの実験結 果に基づくものを除けば $\left(\bar{q} / w_{0} d_{50}\right)_{p}$ は $\left(|\bar{q}| / w_{0} d_{50}\right)_{e}$ の $1.1 \sim 4$ 倍程度であり, 無次元全漂砂量が増大するに

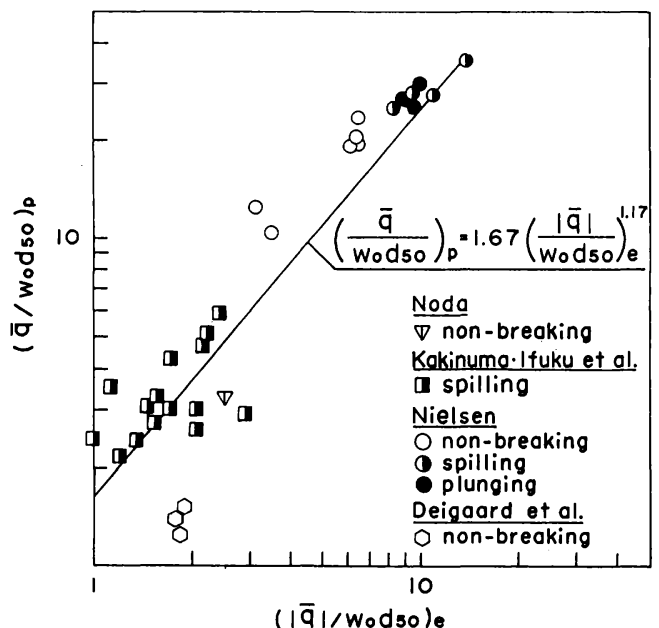

Fig. 11 Comparison of net transport rate computed different shear stresses. 


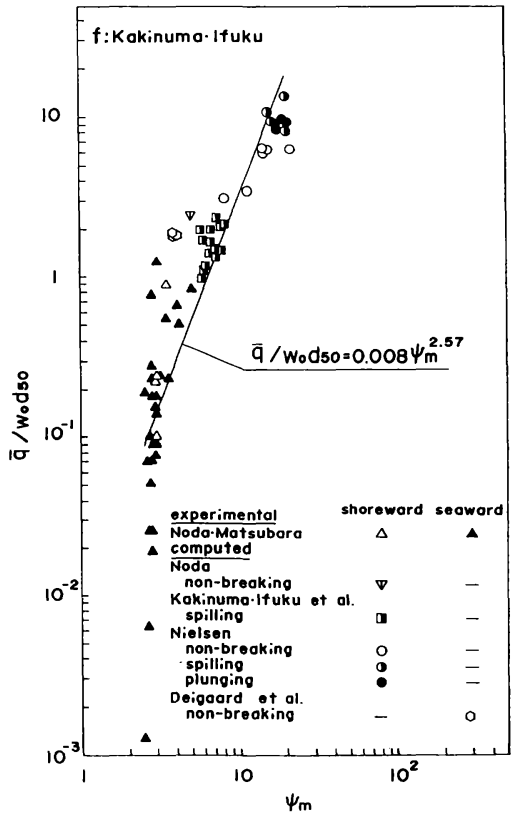

(a)

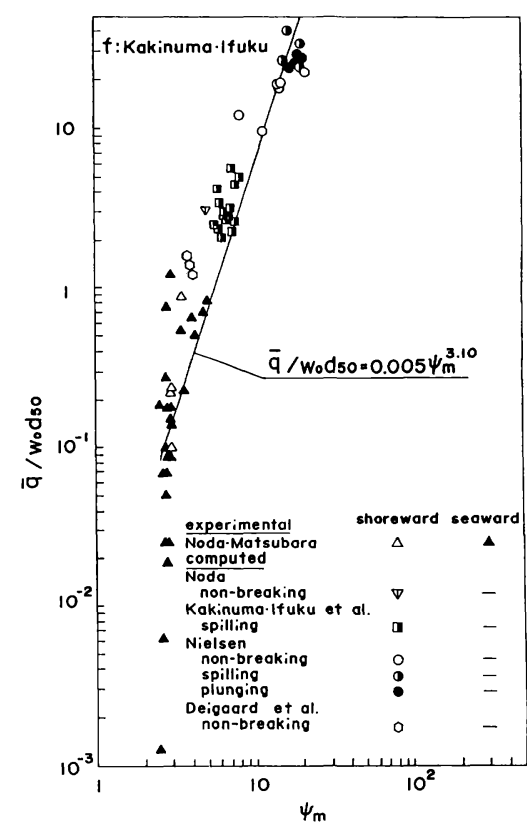

(b)

Fig. 12 Nondimensional net transport rate as a function of Shields parameter.

つれて両者の差は大きくなる.計算に用いた野田,柿沼・ 伊福ら, Nielsen および Deigaard らの波の水深波長比 はそれぞれ $0.15,0.08 \sim 0.14,0.03 \sim 0.06$ および 0.13 〜0.14であり水深波長比が大きいほど無次元全漂砂量 は小さい.

\section{c) 無次元全漂砂量とシールズ数 $\Psi_{m}$}

摩擦応力を式 $(7 \cdot b)$ および式 $(7 \cdot \mathrm{c})$ で評価した場 合の 1 周期平均した無次元全漂砂量とシールズ数との関 係を野田・松原 ${ }^{37)}$ の実験結果とともに示したのが Fig. 12 であり，(a) および (b) はそれぞれ摩擦応力を 式 $(7 \cdot b)$ および式 $(7 \cdot c)$ で評価したものである. 図 中の実線は最小二乗法で求めた回帰式である.なお, シ一 ルズ数を算出する際, 海底摩擦係数は柿沼・伊福の経験 式で算出した.（a）および (b) ともシールズ数が増大 するにつれて無次元全漂砂量は増大する．こうした傾向 は Madsen·Grant が掃流砂が卓越する条件で半周期平 均した漂砂量に対して得た経験式 ${ }^{38)}$ と同一であり, 両対 数紙上で表わされる勾配は（a)ではわずかに小さく，(b) ではほぼ同程度であるが比例定数はかなり小さい。計算 結果は野田・松原の実験結果に比べて, 無次元全漂砂量 の増大の割合が小さいようである.

\section{5. 結論}

現地砕波帯で得た波, 底質および水槽実験で用いた波， 底質をもとに乱流境界層理論, 乱流拡散理論に基づいて 流体中の浮遊砂の濃度分布を算出した結果, 時間に依存
する渦動粘性係数, 乱流拡散係数を用いると岸向き流速 と濃度の位相差の頻度分布のピークの位置およびピーク 値の大小をかなりよく説明し得た。また，水粒子速度に 依存する乱流拡散係数を用いた場合には，境界層外縁の 流速に比例する乱流拡散係数を用いた場合よりも，現地 観測および水槽実験で得た平均浮遊砂濃度の鉛直分布と よりよく一致することを得た。現地観測および水槽実験 で得た結果に基づいて計算した漂砂量は従来の水槽実験 で得た結果とその傾向を同じくすることを見出した.

\section{参 考 文 献}

1) Fairchild, J.C. : Suspended sediment sampling in oscillatory wave motion, Beach Erosion Board, Tech. Memo. 115, 1959.

2) Homma, M. and Horikawa, K. : Suspended sediment due to wave action, Proc. 8 th Coastal Eng. Conf., ASCE, pp. 168〜193, 1962.

3）野田英明：波による底質の浮遊, 第 14 回海岸工学講演会 講演集, pp. 306 314, 1967.

4）本間 仁・堀川清司・鹿島遼一：波による浮遊砂に関す る研究, 第 11 回海岸工学講演会講演集, pp. 159 168, 1964.

5）野田英明・岩佐敏博：波による底質の浮遊機構（1), 第 18 回海岸工学講演会講演集, pp. 349 353, 1971.

6) Sleath, J.F.A. : The suspension of sand by waves, J. Hydraul. Res., Vol. 19, pp. 439 452, 1982.

7) Brennikmeyer, B. M. : Mode and period of sand transport in the surf zone, Proc. 14 th Coastal Eng. Conf., ASCE, pp. 812 827, 1974. 
8) Wright, L. D., Guza, R. T. and Short, A. D. : Dynamics of high energy dissipative surf zone, Marine Geol., Vol. 45, pp. 41 61, 1982.

9) Bakker, W. T. : Sand concentration in an oscillatory flow, Proc. 14 th Coastal Eng. Conf., ASCE, pp. 1129 1148, 1974.

10) Nielsen, P. : Some basic concepts of wave sediment transport, Inst. of Hydrodynamics and Hydraulic Eng., Tech. Univ. of Denmark, Series Paper 20, pp. 1 160, 1979.

11) Stokes, G. G. : On the effect of the internal friction of fluids on the motion of pendulums, Trans. Camb. Philos. Soc., Vol. 9, pp. 20 21, 1981.

12) Jonsson, I. G. and Carlsen, N. A. : Experimental and theoretical investigations in an oscillatory rough turbulent boundary layer, J. Hydraul. Res., Vol. 14, pp. 45 $\sim 60,1976$.

13) Bakker, W. T. and van Doorn, Th. : Near bottom velocities in waves with a current, Delft Hydraulic Lab., Pub. No. 208, 25 p., 1980.

14）浅野敏之・岩垣雄一：底面乱流境界層の水粒子速度に及 ぼす波の有限振幅性の効果, 土木学会第 40 回年次学術講 演会講演概要集, 第 2 部, pp. 523 524, 1985.

15）佐藤慎司・上原啓史・渡辺 晃：乱流モデルによる砂れ ん上の振動流境界層の数值シミュレーション, 第 32 回海 岸工学講演会論文集, pp. 26〜30, 1985.

16）堀川清司・渡辺 晃：表面波による振動流境界層に関す る実験的研究, 第 15 回海岸工学講演会講演集, pp. 16 23, 1968.

17) Trowbridge, J. and Madsen, O.S. : Turbulent wave boundary layers, 2. Second-order theory and mass transport, J. Geophys. Res., Vol.89, No. C 5, pp. 7999 $\sim 8007,1984$.

18) van Doorn, Th. : Experimental investigation of nearbottom velocities in water waves without and with a current, Delft Hydraulic Lab., Rept. M 1423 Part 1, pp. $1 \sim 66,1981$.

19) Kalkanis, G. : Transportation of bed material due to wave action, U.S. Army, Coastal Res. Center, Tech. Memo. 2, 114 p., 1965.

20）柿沼忠男・伊福 誠・栗原 薰: 砕波帯における浮遊砂 濃度に関する二, 三の観測例, 第 32 回海岸工学講演会論 文集, pp. $321 \sim 325,1985$.

21) Nielsen, P. : Field measurements of time-averaged suspended sediment concentrations under waves, Coastal
Eng., Vol. 8, pp. 51 72, 1984.

22) Deigaard, R. J., Fredsøe, J. and Hedegaard, I. B. : Suspended sediment in the surf zone, J. Waterway, Port, Coastal and Ocean Eng., ASCE, pp.115 128, 1986.

23）志村博康：浮流砂を有する水流の諸特性について，土木 学会論文集, 第 46 号, pp. 22 29, 1957.

24）日野幹夫：個体粒子を浮遊した流れの乱流構造の変化, 土木学会論文集, 第 92 号, 1963.

25）柿沼忠男 - 伊福 誠：現地海岸における海底摩擦係数, 第 32 回海岸工学講演会論文集, pp. 234 237, 1985.

26）野田英明：波動による乱流境界層の発達, 第 16 回海岸工 学講演会講演集, pp. 23～27, 1969.

27) Bakker, W.T. and van Doorn, Th. : Near bottom velocities in waves with a current, Proc. 16 th Coastal Eng. Conf., ASCE, pp. 1394 1413, 1978.

28) Nielsen, P. : Dynamics and geometry of wave generated ripples, J. Geophys. Res., Vol.86, No. C 7, pp.6467 6472,1981 .

29) Scheidegger, A. E. : General theory of dispersion in porous media, J. Geophys. Res., Vol.66, pp.3273 3278, 1961.

30）土木学会編：水理公式集, 丸善, p. 47, 1971.

31) Schlichting, H. translated by J. Kestin : Boundary Layer Theory, 6 th ed., McGraw-Hill, p.108, 1968.

32）愛媛県水産試験場：烼灘漁海況速報, 1983.

33) U. S. Army Coastal Eng. Res. Center : Shore Protection Manual, Vol.2, p. 2-35, 1977.

34) Einstein, H. A. and El-Samni, El S. A. : Hydrodynamic forces on a rough wall, Rev. Mod. Phys., pp. 520 524, 1949.

35) Einstein, H. A. : The bed-load function for sediment transportation in open channel flows, USDA, Soil Conservation Service, Technical Bulletin, No.1026, pp. 1 71, 1950.

36) Engelund, F. and Fredsøe, J. : A sediment transport model for straight alluvial channels, Nordic Hydrology, Vol. 7, pp. 293 306, 1976.

37）野田英明・松原雄平: 汀線に直角方向の漂砂, 第 25 回海 岸工学講演会論文集, pp. 246 249, 1978.

38) Madsen, O.S. and Grant, W. D. : Quantitative description of sediment transport by waves, Proc. 15 th Coastal Eng. Conf., ASCE, pp. 1093 1112, 1976.

(1988. 4.30 - 受付) 